\title{
Growth of Acer saccharum seedlings in deeply shaded understories of northern Wisconsin: effects of nitrogen and water availability
}

\author{
Michael B. Walters and Peter B. Reich
}

\begin{abstract}
Availability of soil nitrogen, soil moisture, and light were examined, along with the growth, biomass allocation, and leaf nitrogen concentration of naturally established Acer saccharum Marsh. seedlings, in the understories of 12 forest sites in northern Wisconsin. The sites represented a nutrient and moisture gradient (poor to rich) according to a habitat classification system. We asked (1) Are seedling growth rates, biomass allocation patterns, and leaf nitrogen related to soil water and nitrogen availability? and (2) Do soil resource rankings predicted by habitat classifications mirror our direct observations? Across sites compared in a low-light data set (plots with $<5 \%$ canopy openness), rich sites had 2- to 4 -fold higher seedling growth, percent leaf nitrogen, nitrogen mineralization rates, and nitrification rates than poor sites. Seedling growth in low light correlated $(P \leq 0.05)$ positively with nitrification, total nitrogen mineralization, percent leaf nitrogen, soil moisture, and organic carbon, and negatively with fine root density. In multiple regression, soil moisture $(P=0.033)$ and nitrification $(P=0.015)$ together explained $79 \%$ of the variation in growth. Thus, seedling growth in shade was enhanced on richer sites in part because of higher nitrate $\mathrm{N}$ and water availability. This has potential implications for forest dynamics, since the probability of sugar maple becoming the dominant woody regeneration in any given understory may be partially dependent upon the level of soil resources.

Résumé : La disponibilité de l'azote du sol, de l'humidité du sol et de la lumière, de même que la croissance, l'allocation en biomasse et la concentration foliaire en azote ont été étudiées sur des semis de Acer saccharum Marsh., en sous-étage de 12 stations forestières du Nord du Wisconsin. Les stations représentaient un gradient nutritif et d'humidité de pauvre à riche à l'intérieur d'un système de classification des habitats. Les auteurs désiraient répondre aux questions suivantes : (1) le taux de croissance des semis, leur patron d'allocation en biomasse et l'azote foliaire sont-ils reliés à l'eau du sol et à la disponibilité en azote? et (2) la disponibilité relative des ressources du sol prédite par la classification des habitats reflète-t-elle les observations directes des auteurs? Parmi les stations où l'intensité lumineuse était faible, c'est-à-dire où l'ouverture du couvert dans les parcelles était inférieure à $5 \%$, les stations riches présentaient des taux de croissance des semis, des teneurs en azote foliaire ainsi que des taux de minéralisation de l'azote et de nitrification de deux à quatre fois supérieurs comparativement aux stations pauvres. La croissance des semis sous faible éclairement était corrélée $(P \leq 0,05)$ positivement avec la nitrification, la minéralisation de l'azote, le contenu en azote foliaire, l'humidité et le carbone organique du sol, et négativement avec la densité des racines fines. Dans des régressions multiples, l'humidité du sol $(P=0,033)$ et la nitrification $(P=0,015)$ expliquaient conjointement $79 \%$ de la variation de la croissance. Ainsi, la croissance des semis en milieu ombragé était favorisée sur les stations riches en partie par les teneurs plus élevées en nitrates et une plus grande disponibilité en eau. Ceci pourrait avoir des conséquences sur la dynamique forestière; la probabilité qu'un érable à sucre forme la régénération ligneuse dominante dans un sous-étage donné peut dépendre partiellement du niveau des ressources du sol.

[Traduit par la Rédaction]
\end{abstract}

\section{Introduction}

In forest understories, light is probably the single most important factor limiting growth and survival of established tree seedlings and saplings (Pearcy 1983; Canham 1988; Pacala et al. 1994; Kobe et al. 1995; Walters and Reich 1996). However, trenching and fertilization experiments (reviewed by Grubb 1994) suggest that water and (or) nutrients may sometimes limit growth in forest understories, especially on poor soils. Furthermore, soil resource growth limitation, even in lowlight understories, is predicted by multiple resource limitation

M.B. Walters. ${ }^{1}$ Faculty of Natural Resources and

Environmental Studies, University of Northern British

Columbia, Prince George, BC V2N 4Z9, Canada.

P.B. Reich. Department of Forest Resources, University of Minnesota, St. Paul, MN 55108, U.S.A.

Author to whom all correspondence should be addressed. theory (Givnish 1986; Chapin et al. 1987; Tilman 1988). Lower seedling growth is predicted in nutrient- and (or) waterpoor than rich forest understories because of (1) a lower proportion of biomass in leaves due to higher root allocation (Lambers and Poorter 1992; Mooney et al. 1995) and (or) (2) decreased leaf photosynthesis due to leaf nutrient and (or) water limitation (Mooney et al. 1995). In one of the few experiments examining these issues for naturally established plants, Peace and Grubb (1982) found that greater growth of Impatiens parviflora in fertilized understories was due to a greater fraction of plant mass in leaves.

Sugar maple (Acer saccharum Marsh.) is a common latesuccessional canopy dominant in dry-mesic to mesic northern temperate ecosystems (Curtis 1959). It is among the most shade tolerant trees in these ecosystems, a trait that is likely due to a syndrome of traits, including a large seed (Curtis 1959; Beatty 1984), relatively high rates of growth and survival in low light (Lorimer 1983; Pacala et al. 1994; Kobe et al. 1995; 
Walters and Reich 1996; but see Sipe and Bazzaz 1995), and an incompletely understood combination of physiological, morphological, and tissue conservation traits that enhance growth and survival in low light (Givnish 1988; Lei and Lechowicz 1990; Sipe and Bazzaz 1994; Walters and Reich 1996). In northern Wisconsin, sugar maple seedlings are common on sites ranging from moderately fertile, dry-mesic forests, with presumed Pinus strobus L. - Quercus rubra L. climax associations, to rich, fertile, wet-mesic sugar maple dominated forests (Curtis 1959; Kotar et al. 1988). In this region, variation in site nutrient and water availability is thought to be driven by dominant vegetation composition, disturbance history, and postglacial topography and soil texture (Curtis 1959; Pastor et al. 1984; Kotar et al. 1988; Clark 1990; Zak and Pregitzer 1990; Reich et al. 1996). Although sugar maple seedlings are distributed broadly, trees are not well represented in the overstory of poorer sites. Sugar maple may compete poorly with $P$. strobus, $Q$. rubra, and Acer rubrum L. on these sites if its growth and survival is more sensitive to low soil resource availability. Alternatively, abundant sugar maple seedlings in $Q$. rubra and $P$. strobus dominated stands may indicate a shift in future overstory composition resulting, perhaps, from fire suppression in areas that historically burned more frequently (Host et al. 1987).

In this study we use naturally regenerated sugar maple seedlings growing on sites chosen to represent a range of nutrient and water availabilities to investigate the effects of soil resources on growth in low-light forest understories. Our primary questions for sugar maple seedlings growing in low-light forest understories were as follows:

(1) Do sites classified as having higher nutrient and water availability support higher growth rates than poorer sites?

(2) Is growth related to indices of soil nitrogen $(\mathrm{N})$ and water availability?

(3) Are patterns in biomass allocation and leaf $\mathrm{N}$ consistent with variation in growth and indices of soil resource availability?

We tested these questions by examining interrelationships between seedling growth, leaf $\mathrm{N}$, biomass allocation, canopy openness (a measure of light availability), and indices of soil resource availability $(\mathrm{N}$ mineralization and nitrification rates, organic carbon, texture, water content, fine root density, and seedling layer coverage).

\section{Sites, materials, and methods}

\section{Study sites}

We located 12 approximately 1-ha mature forest sites in Forest, Vilas, and Oneida counties, Wisconsin, U.S.A., in the summer of 1990 . We chose sites that (1) collectively spanned the range of habitat types (i.e., the presumed range of soil nutrient and water availabilities) where sugar maple seedlings are common in the region and (2) avoided areas with many sapling and adult evergreen conifers, since differences in leaf habit would complicate estimations of seedling light availability. Locating candidate sites was aided by topographically mapped glacial features (e.g., Attig 1985) and a habitat type system that uses differences in understory composition as an indicator of site nutrient and water availability (Kotar et al. 1988). Locating a balanced number of sites for each habitat type was not a priority, since we considered variation in seedling growth and belowground resource availability to be continuous.

The names of our 12 sites follow the nomenclature of Kotar et al. (1988) for habitat types, followed by a number to distinguish sites within a habitat type. Habitat type names consist of the presumed climax tree genus and understory species associations. Habitat type order here and left to right in Tables 1 and 2 is from highest to lowest presumed nutrient and water availability: Acer (saccharum) - Viola Osmorhiza (AViO); Acer (saccharum) - Tsuga (canadensis)Dryopteris (ATD); Acer (saccharum) - Viburnum (AVVib); and Pinus (strobus) - Maianthemum - Vaccinium (PMV). The maximum distance between sites was $70 \mathrm{~km}$. $\mathrm{AViO}_{1}$ and $\mathrm{AViO}_{2}$ were lightly partially cut 5 years before site establishment, and $\mathrm{AViO}_{4}$ and $\mathrm{AVVib}_{4}$ were partially cut 4 years before establishment. For the other six sites there was no evidence of recent disturbance, aside from an occasional single tree death. Data are incomplete for $\mathrm{PMV}_{3}$, since it was destroyed by home construction in Autumn 1991.

In each site we established 10-point plots in a grid with $15-\mathrm{m}$ spacing between plots. Plot radii varied and were $1 \mathrm{~m}$ for sugar maple seedling growth and resource availability measurements; for composition, basal area, and numbers of stems, $3 \mathrm{~m}$ for saplings and shrubs $(>0$ and $<5 \mathrm{~cm} \mathrm{DBH})$ and $5 \mathrm{~m}$ for trees $(\geq 5 \mathrm{~cm}$ $\mathrm{DBH})$; and for seedling layer composition and coverage, the area between 1 and $2 \mathrm{~m}$ radius from plot center. The seedling layer was herbs, shrubs, tree seedlings, and ferns that were of equal or lesser stature than the average height of the sugar maple seedling canopy. This layer represented potential competition that could not be quantified with our light availability measurements. Stand age was estimated from the largest cohort of the 15-20 randomly chosen increment cored trees per site.

\section{Seedlings}

Seedlings selected for measurement were the closest to plot center if they satisfied the following criteria: (1) not visibly deformed by herbivory or stem dieback; (2) not shaded by the leaves of competing vegetation within a distance of 1 to $1.5 \mathrm{~m}$ (i.e., 20 times the width of the shading foliage, LAI 2000 users manual, LI-COR Inc., Lincoln, Nebr.); (3) less than $1 \mathrm{~m}$ tall. We harvested groups of seedlings in 3 different years. In August 1990 we hand excavated 85 seedlings (10 to $100 \mathrm{~cm}$ tall) with root systems as intact as was possible, from $\mathrm{AViO}_{1}, \mathrm{AViO}_{2}, \mathrm{AVVib}_{1}$, and $\mathrm{PMV}_{1}$. These excavations (2-3 seedlings per plot) were made $2 \mathrm{~m}$ south of plot centers. In August 1991 we hand excavated $1-2$ small ( 9 to $25 \mathrm{~cm}$ tall) seedlings per plot from the eight sites $(n=89)$ where seedlings were not harvested in 1990. We harvested smaller seedlings in 1991 than 1990, since seedling excavations were extremely time-consuming. In 1992 we collected aboveground portions of $1-3$ seedlings ( 10 to $100 \mathrm{~cm}$ tall) from each plot on the eleven sites $(n=254)$. We divided seedlings into leaves, stems, and, if harvested, roots, dried the material in a forced air oven $\left(70^{\circ} \mathrm{C}\right)$ and measured mass. After drying, total stem length was measured as the sum of the lengths of the terminal leader and all lateral branches. We estimated seedling ages and annual total stem length growth increment for the current and previous year using annual bud scars. Relative stem length growth was calculated with the formula $\ln ($ total stem length year $a+1)-\ln ($ total stem length year $a)$, where $\ln$ is the natural logarithm. Stem length growth data harvested in 1990 and 1991 were consistent with the larger data set for seedlings harvested in 1992. Thus, for the sake of brevity, 1990 and 1991 harvests growth data are not presented. We also recorded the number of times the primary stem had been browsed and (or) died back over the life of the seedling. For excavated seedlings $(1990,1991)$, we calculated leaf mass ratio (leaf mass.(total plant mass) $)^{-1}$ ). For 1992 seedlings we visually estimated the percent partial leaf loss to herbivores and mechanical damage and measured total organic leaf $\mathrm{N}$ using a microKjeldahl assay (University of Wisconsin Soil and Plant Analysis Laboratory).

Stem length growth is an index of volume growth and occupancy, which is an important index of competitive status (Küppers 1985). However, relative dry mass growth $\left(\mathrm{g} \cdot \mathrm{g}^{-1} \cdot\right.$ year $\left.^{-1}\right)$ is also an important index (and a more traditional measure) of seedling performance in forest understories, since it is closely related to carbon gain (Givnish 
Table 1. Site vegetation and soil characteristics for ALL LIGHT data.

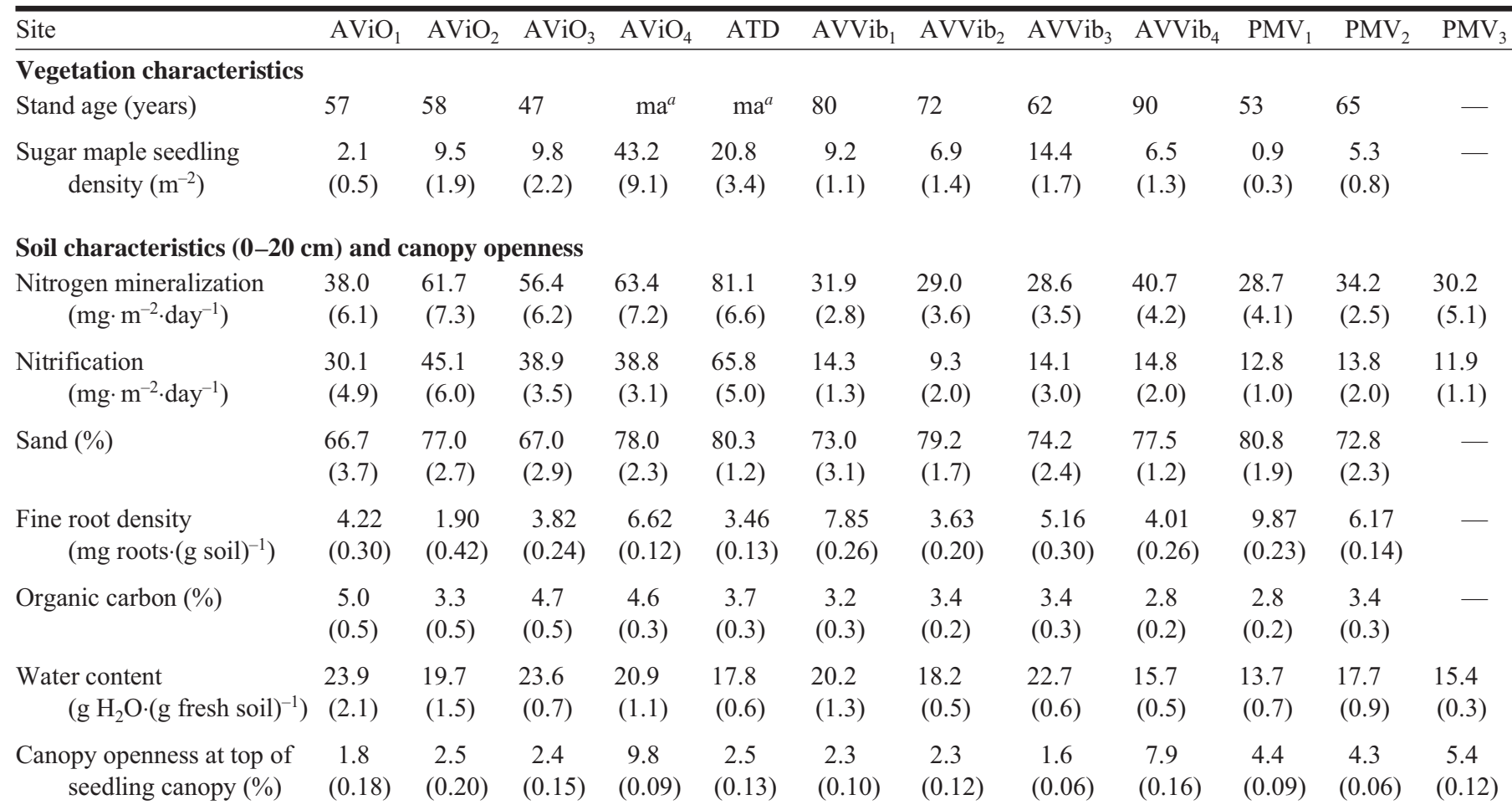

\section{Sugar maple seedling characteristics}

Stem growth

$\left(\mathrm{cm} \cdot \mathrm{cm}^{-1} \cdot\right.$ year $\left.^{-1}\right)$

1991

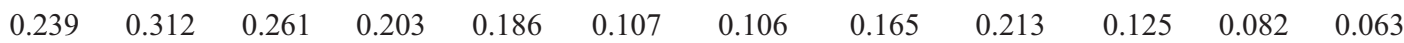

$\begin{array}{lllllllllllll}0.039 & (0.035) & (0.039) & (0.031) & (0.021) & (0.013) & (0.017) & (0.030) & (0.034) & (0.023) & (0.011) & (0.017)\end{array}$

1992

$\begin{array}{lllll}0.151 & 0.280 & 0.136 & 0.192 & 0.173\end{array}$

0.101

0.087

$0.095 \quad 0.191$

$0.121 \quad 0.078$

$\begin{array}{llllll}(0.029) & (0.036) & (0.018) & (0.023) & (0.015) & (0.012)\end{array}$

(0.011)

(0.011)

(0.040)

(0.016) (0.006)

Leaf nitrogen $(\%)$

$\begin{array}{cccccc}2.09 & 2.02 & 1.72 & 1.09 & 1.82 & 1.23 \\ (0.09) & (0.04) & (0.07) & (0.07) & (0.05) & (0.13)\end{array}$

1.31

1.56

1.15

$1.27 \quad 1.13$

Leaf mass ratio ${ }^{b}$

$0.19 \quad 0.19$

$0.26 \quad 0.21$

$0.24 \quad 0.18$

0.18

$(0.06)$

$(0.05)$

(0.20) (0.06)

$\left(\mathrm{g}\right.$ leaves $\left.\cdot(\mathrm{g} \text { plant })^{-1}\right)$

Note: Site habitat type order, left to right, is from highest (AViO) to lowest (PMV) presumed nutrient and water availability (Kotar et al. 1988). Nitrification and $\mathrm{N}$ mineralization measurements were taken in 1991; leaf mass ratio was determined for a combination of seedlings harvested in 1990 and 1991. The 1991 growth rates were measured on seedlings harvested in 1992 except for $\mathrm{PMV}_{3}$, which is for seedlings harvested in 1991. All other measurements were taken in 1992. Values are means of 9-10 plots per site ( $\pm 1 \mathrm{SE})$ except for stand age. See Sites, materials, and methods for further information.

${ }^{a}$ Multiple aged.

${ }^{b}$ Least squares means adjusted by the natural logarithm of seedling age.

1988) and survival in these carbon-limited, low-light environments (Walters and Reich 1996). Stem length and plant mass should scale, but environment could affect their relationship (e.g., etiolation in low light). We estimated relative mass growth as $\ln ($ mass year $a+1)-$ $\ln$ (mass year $a$ ) by developing a predictive least squares regression equation between $\ln$ (total stem length) and $\ln$ (mass) for seedlings harvested in 1990.

On five of the sites we measured light saturated photosynthetic rates $\left(>550 \mu \mathrm{mol}\right.$ quanta $\left.\cdot \mathrm{m}^{-2} \cdot \mathrm{s}^{-1}\right)$ from 11:00 to $13: 00$, July $15-20$, 1991, with an ADC LCA-2 portable gas exchange system operated in the differential mode (Analytical Development Corporation, Hoddesdon, England). The $\mathrm{CO}_{2}$ analyzer was calibrated against known $\mathrm{CO}_{2}$ standards July 14, then reconfirmed July 22 . For each site we measured a leaf from each of two seedlings that were within $1 \mathrm{~m}$ of each plot center (20 leaves total per site). On $\mathrm{PMV}_{3}$ seedling density was low, so we extended plot radii up to $3 \mathrm{~m}$ to obtain our measurement seedlings. It was necessary to use detached leaves for photosynthesis measurements, since light-saturated conditions for attached leaves were infrequent. Detachment had no effect on photosynthetic rates within the time frame ( $<1 \mathrm{~min})$ that measurements were taken (M.B. Walters, unpublished data).

\section{Canopy openness}

Canopy openness, an index of light availability, was estimated at the top of the seedling canopy for each plot with paired LAI-2000 plant canopy analyzers (LI-COR Inc., Lincoln, Nebr., U.S.A.) during midsummer in 1991 and 1992. Seedling measurements were taken when the sky was uniformly overcast with one LAI-2000 unit, while another identical unit, placed in a nearby clearing $(<1 \mathrm{~km}$ away), recorded open-sky values. The units were later linked to calculate values. During measurements, the sensor on both units was fitted with $180^{\circ}$ view caps, and the sensors were oriented to the same azimuth so 
Table 2. Spearman's rank correlation coefficients for seedling and soil characteristics based on site means for LOW LIGHT data.

\begin{tabular}{|c|c|c|c|c|c|c|c|c|c|c|}
\hline & \multicolumn{2}{|c|}{ Stem growth rate } & \multirow[b]{2}{*}{ Leaf $\% \mathrm{~N}$} & \multirow[b]{2}{*}{ Nitrification } & \multirow[b]{2}{*}{$\mathrm{N}$ mineralization } & \multirow[b]{2}{*}{$\%$ sand } & \multirow{2}{*}{$\begin{array}{l}\% \text { soil } \\
\text { carbon }\end{array}$} & \multirow{2}{*}{$\begin{array}{l}\text { Fine root } \\
\text { density }\end{array}$} & \multirow{2}{*}{$\begin{array}{l}\text { \% canopy } \\
\text { openness }\end{array}$} & \multirow[b]{2}{*}{$\%$ water } \\
\hline & 1991 & 1992 & & & & & & & & \\
\hline \multicolumn{11}{|l|}{ Stem growth rate } \\
\hline 1991 & & $0.90 * *$ & $0.95 * *$ & $0.80 * *$ & 0.60 & -0.22 & $0.72 *$ & $-0.73^{*}$ & $-0.72 *$ & 0.65 \\
\hline 1992 & & & $0.85^{* *}$ & $0.83 * *$ & $0.73^{*}$ & -0.10 & 0.58 & -0.58 & -0.41 & 0.38 \\
\hline Leaf $\% \mathrm{~N}$ & & & & $0.73 *$ & 0.57 & -0.12 & $0.77 *$ & $-0.75^{*}$ & $-0.70^{*}$ & 0.57 \\
\hline Nitrification & & & & & $0.87 * *$ & -0.08 & $0.70 *$ & $-0.68^{*}$ & -0.27 & 0.35 \\
\hline$\%$ soil carbon & & & & & & & & $-0.67^{*}$ & -0.40 & 0.63 \\
\hline \multicolumn{11}{|l|}{ Fine root } \\
\hline density & & & & & & & & & 0.38 & -0.25 \\
\hline \multicolumn{11}{|l|}{$\%$ canopy } \\
\hline openness & & & & & & & & & & $-0.78^{*}$ \\
\hline
\end{tabular}

Note: Probability $>|\rho|$ is indicated as $*, P<0.05 ; * *, P<0.01 . n=9$ sites in all cases. See Fig. 5 legend for the number of plots used. All parameters were measured in 1992 except $\mathrm{N}$ mineralization rates, nitrification rates, and percent water, which were measured in 1991.

that they sampled the same half of the canopy hemisphere. Because of this sampling regime we alternated the sampling direction by $180^{\circ}$ among replications when possible, so that canopy halves were equally sampled. For half of the sites, clearings large enough to accommodate both halves of the remote sensors' measurement hemisphere could not be found within a reasonable distance. In these cases, we placed the tripod supporting the remote LAI-2000 in shallow water along a lake edge, and canopy openness data were always collected for the same half hemisphere. For brevity, we focus on 1992 canopy openness values, since (1) we had more replicates per plot (2-4) than in 1991 (1-2); (2) more sites were measured in 1992 (11) than in 1991 (9); (3) among plots canopy openness values were related between years (Kruskal-Wallis test of ranked sums, $\chi^{2}=152.53, \mathrm{df}=88, P<0.0001$ ); and (4) for plots that we measured in both 1991 and 1992, mean canopy openness was not significantly different between years (Student's $t$ test, $n=88, P=0.21$ ). The 1991 data are used for $\mathrm{AViO}_{1}$, since a canopy tree fell, creating a canopy gap a few days before 1992 light and seedling measurements, and for $\mathrm{PMV}_{3}$, since the site was destroyed by home construction in Autumn 1991.

\section{Soil characteristics}

Most measurements were taken for the first $20 \mathrm{~cm}$ of the soil profile, since (1) we found the vast majority of sugar maple seedling roots in this profile (M.B. Walters, personal observation) and (2) previous work has shown that most $\mathrm{N}$ mineralization occurs in this region (Binkley and Hart 1989).

Nitrogen mineralization rates were determined with a modified core - ion exchange resin method (core-IER) (DiStefano and Gholz 1986) for two in-field incubation periods, May 26 - July 9 and July 17 September 15 of 1991. There were two replications per plot (20 per site) per incubation period. For each replication, paired $5.08 \mathrm{~cm}$ diameter $\times 20 \mathrm{~cm}$ deep cores were taken with PVC tubes after carefully removing forest floor duff. Soil in the first core (initial core) was collected and transported to the University of Wisconsin to determine initial water content and $2 \mathrm{M} \mathrm{KCl}$ extractable $\mathrm{NH}_{4}$ and $\mathrm{NO}_{3}$ pools (see procedure below). The second core (incubation core), still inside the PVC tube, was carefully pulled from the forest floor. A nylon stocking containing $50 \mathrm{~mL}$ of the cation and anion exchange resin beads (J.T. Baker No. M-614, 16-50 mesh, mixed-bed ion exchange resins) was placed snugly in the PVC tube at the base of the intact core. Prior to their placement, the IER bags were extracted in $2 \mathrm{M} \mathrm{KCl}$ for $24 \mathrm{~h}$ in order to assure noncontamination and high exchange capacity. The core, in the tube, was then placed back in the hole, material from the forest floor above the core was replaced, and the core was allowed to incubate. After the incubation period ( 47 or 63 days), the soil core and
IER bags were transported to the University of Wisconsin and kept refrigerated $(<7$ days $)$ at $2{ }^{\circ} \mathrm{C}$. Soil was well mixed and cleaned to a $<2$-mm fraction. Then 40 -g field-moist soil samples and the IER bags were each extracted in $100-\mathrm{mL} 2 \mathrm{M} \mathrm{KCl}$. Subsamples of soils used for the extracts were dried at $105^{\circ} \mathrm{C}$ to determine water content. $\mathrm{NO}_{3}-\mathrm{N}$ and $\mathrm{NH}_{4}-\mathrm{N}$ in the extract solutions were determined by the University of Wisconsin Soil and Plant Analysis Laboratory. Total N was measured by persulfate-peroxide digestion in a block digestor followed by analysis for ammonium on a Technicon AutoAnalyzer. $\mathrm{NO}_{3}-\mathrm{N}$ concentrations were calculated as the difference between total $\mathrm{N}$ and $\mathrm{NH}_{4}-\mathrm{N}$ concentrations. $\mathrm{N}$ mineralization rates were calculated on an area basis from the difference in $\mathrm{N}$ concentrations between initial and incubated core soil samples plus the amount of $\mathrm{N}$ extracted from the gel beads divided by the incubation time. Rates of nitrification were calculated similarly by considering only $\mathrm{NO}_{3}-\mathrm{N}$. Calculated N mineralization and nitrification rates for the two incubation periods were averaged prior to analysis.

Percent sand and soil organic carbon were determined from subsamples of single, well-mixed, cleaned ( $>2 \mathrm{~mm}$ removed) $5.08 \times$ $20 \mathrm{~cm}$ cores for each plot. Soil carbon was calculated as mass at $365^{\circ} \mathrm{C}$ minus mass at $105^{\circ} \mathrm{C}$ (Black et al. 1965). Soil texture was determined with two methods (Black et al. 1965). Percent sand was determined for all sites as the proportion of cleaned soil sample retained following washing in a $53-\mu \mathrm{m}$ sieve. Percent fine silt and clay (particle diameter $<5.5 \mu \mathrm{m}$ ) was determined with the hydrometer method (Black et al. 1965) for four sites $\left(\mathrm{AViO}_{1}, \mathrm{AViO}_{2}, \mathrm{AVVib}_{1}\right.$, $\left.\mathrm{PMV}_{1}\right)$ at two soil depths (0-20 and 30-50 cm from the surface). Soil water content was determined for the initial $\mathrm{N}$ mineralization cores collected on May 26 and July 17, 1991 (i.e., two $5.08 \times 20 \mathrm{~cm}$ cores per plot $=20$ per site per measurement date). Percent soil water on a mass basis $\left(100 \cdot\left[\mathrm{g} \mathrm{H}_{2} \mathrm{O} \cdot(\mathrm{g} \text { field fresh soil })^{-1}\right]\right)$ was calculated from field-fresh and ovendried $\left(105^{\circ} \mathrm{C}\right)$ mass. Values from the two measurement dates were averaged for each plot prior to analysis. Density of fine roots (mg roots $<2 \mathrm{~mm}$ diameter. $\left(\mathrm{g}\right.$ ovendried soil) ${ }^{-1}$ ) was determined August 1992 for the first $20 \mathrm{~cm}$ in each plot on samples obtained with a shovel.

\section{Design and data analysis}

Plots (10 for each of 12 sites) were considered experimental units. For some measurements (e.g., seedling growth, $\mathrm{N}$ mineralization cores, leaf N, canopy openness) more than one measurement was taken per plot per measurement event and (or) over the growing season. These values were averaged and plot means were used for analysis or in the case of leaf N, plants were pooled and one value was obtained. 
Fig. 1. Vegetation composition and density of tree, sapling, and seedling layers for each site. Site habitat type nomenclature and rationale for the ordering of sites are in Table 1 note and Sites, materials, and methods.
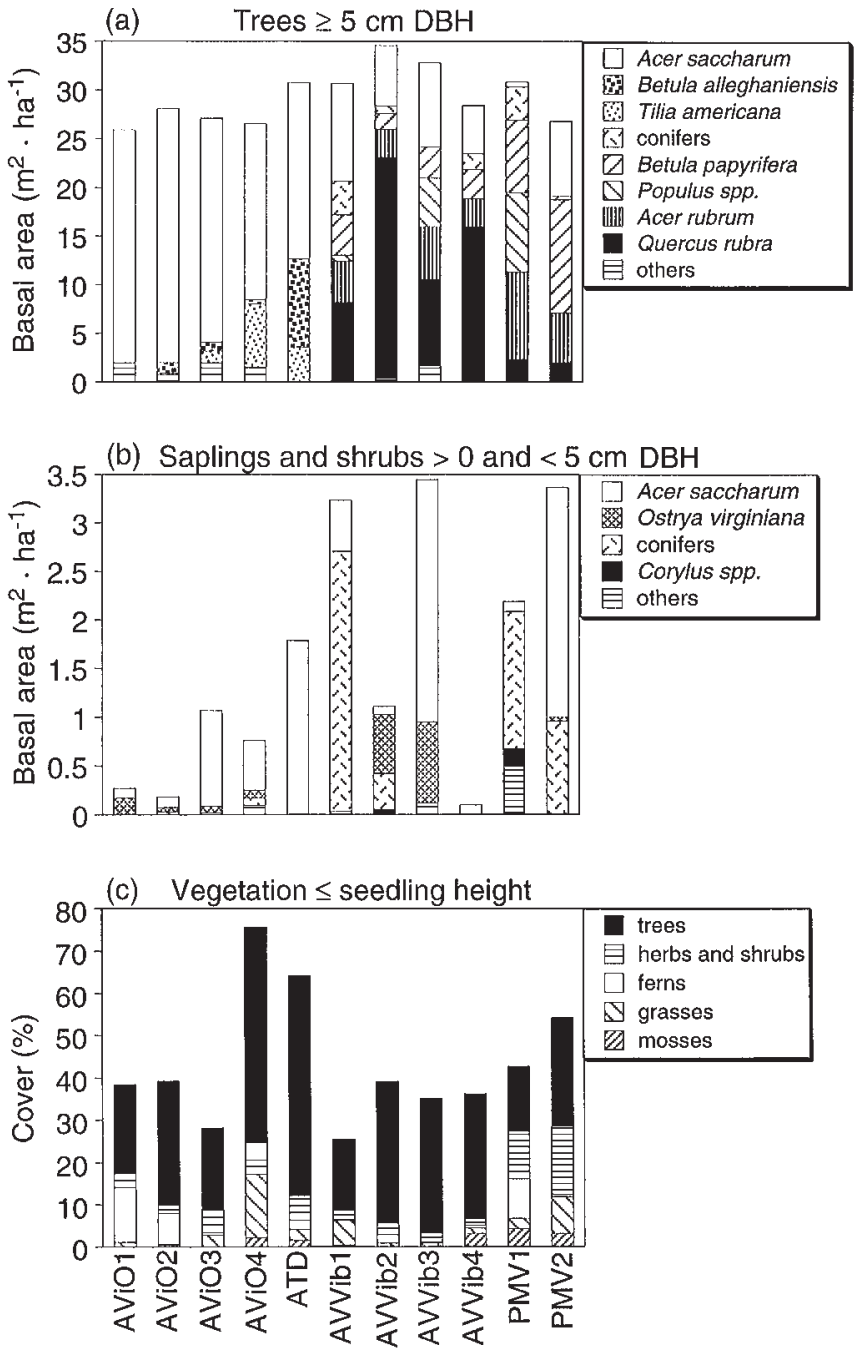

For our initial analysis, we examined relationships of resource availability, seedling age, and mass with seedling growth, leaf mass ratio, and leaf $\mathrm{N}$ for plot data with analysis of covariance (ANCOVA) (JMP, SAS Institute Inc., Cary, N.C.) using the general linear model

$$
y_{i}=\beta_{0}+\beta_{1} x_{1 i}+\beta_{2} x_{2 i}+\varepsilon_{i}
$$

where $y_{i}$ is the predicted value for the $i$ th observation of the response variable; $\beta_{0}$ is the intercept for the full model; $\beta_{1}$ is the slope for effect $x_{1} ; x_{1 i}$ is $i$ th observation of $x_{1}$, a continuous predictor effect; $\beta_{2}$ is the slope for effect $x_{2} ; x_{2 i}$ is the $i$ th observation of $x_{2}$, a nominal predictor effect; and $\varepsilon_{i}$ is the unmeasured error associated with $y_{i}$.

We used this approach for two interrelated reasons. First, we wanted to determine whether resource availability - seedling characteristic relationships were significant on the spatial scale of plots (i.e., significant after the effect of sites were removed). If they were not then we considered further analyses on a plot basis inappropriate and reduced data to site means for further analyses. For ANCOVA we considered site as the nominal predictor $\left(x_{2}\right)$ and canopy openness or soil characteristics as continuous predictors $\left(x_{1}\right)$ of seedling growth, leaf mass ratio, and leaf $\mathrm{N}(y)$. In combination with site, all possible continuous predictors were tested one at a time and considered significant if their partial $P<0.05$, because ANCOVA removes all site effects from the model before considering the continuous predictor variable. Second, since our focus was on belowground resource effects on seedling traits in low light, we had to determine whether these relationships were potentially confounded by variation in canopy openness, seedling age, or mass across and within sites. To do this we added site as a nominal predictor and either canopy openness, seedling age, or seedling mass as a continuous predictor of leaf $\mathrm{N}$, leaf mass ratio, or growth. If relationships were significant after site effects were removed (partial $P<0.05$ ), we then investigated the potential for adjusting site means by the covariate. This was considered a necessary precaution, since average canopy openness (Table 1), seedling age, and mass varied across sites (e.g., average age range in 1992; 7.2 years $\left(\mathrm{AViO}_{3}\right)$ to 18.4 years $\left.\left(\mathrm{AVVib}{ }_{2}\right)\right)$ and growth rates and leaf mass ratios can decrease with seedling mass and age, at least within a growing season in high light (Walters et al. 1993). Prior to inclusion in ANCOVA models, several transformations of continuous variables were tested when scatterplots of potential variable pairs suggested nonlinear relationships, heteroscadasticity, or non-normal distributions. Depending on ANCOVA results, data were reduced to site means based on the average of plots for further analyses, and (or) were analyzed on a plot basis for all sites pooled or for sites pooled by habitat type with least squares linear regression.

For data reduced to site means we present two data sets: ALL LIGHT (the average of all plots for a site) and LOW LIGHT (average of plots with $<5 \%$ canopy openness on each site). Our rationale for using a LOW LIGHT data set rather than adjusting seedling traits by the covariate canopy openness is provided in Results. Three of our sites $\left(\mathrm{AViO}_{4}\right.$, $\mathrm{AVVib}_{4}, \mathrm{PMV}_{3}$ ) had all plots $\geq 5 \%$ light and thus are not included in low light. The number of plot values used for site means in LOW LIGHT varied slightly among measured characteristics and were $\mathrm{AViO}_{1}$ (6-7), $\mathrm{AViO}_{2}$ (7-8), $\mathrm{AViO}_{3}$ and ATD (8-9), AVVib 1 (10), AVVib and $\mathrm{AVVib}_{3}(9-10), \mathrm{PMV}_{1}(4-5), \mathrm{PMV}_{2}$ (7). For site means, general trends in habitat types are discussed, but these discussions often exclude ATD, since there was only one replication of this habitat type, thus precluding generality. For site means in LOW LIGHT, relationships among soil and plant traits are compared with Spearman's rank correlation. We chose this technique because it is insensitive to nonnormal data distributions and variation in specific form (linear or otherwise). We analyzed the combined effects of pairs of soil resource - competition indices on seedling growth for site means in LOW LIGHT using least squares multiple regression. We limited this analysis to pairs of predictor variables because of low $n(n=9)$. Every paired combinations of the following seven variables were used to predict 1991 and 1992 growth rates (42 total tests): percent soil water, percent soil organic carbon, percent sand, fine root density, nitrification rates, $\mathrm{N}$ mineralization rates, and seedling layer coverage.

\section{Results}

\section{Site vegetation and soil characteristics}

Most stands had an identifiable even-aged cohort ranging from 47 to 90 years old $($ Table 1$)$. ATD was multiple aged $($ mean $=$ 73 years, range $24-195$ years) and showed no signs of ever having been cut. $\mathrm{AViO}_{4}$ was multiple aged (mean $=74$ years, range 24-153 years) and had recently been partially cut. Among sites, basal area ranged from 25.9 to $34.6 \mathrm{~m}^{2} \cdot \mathrm{ha}^{-1}$ for trees and from 0.19 to $3.46 \mathrm{~m}^{2} \cdot \mathrm{ha}^{-1}$ for saplings and shrubs (Fig. 1). Sugar maple trees and saplings dominated AViO sites and ATD (Fig. 1, Table 1). On AVVib sites Q. rubra and sugar maple trees were important, as were saplings of sugar maple, Ostrya virginiana (Mill.) K. Koch., and conifers (mostly Abies balsamea (L.) Mill.). Species mixtures dominated the tree layer on PMV sites, and sugar maple, A. balsamea, and Corylus spp. $\left(\mathrm{PMV}_{1}\right)$ were well represented in the sapling layer. Tree seedlings represented the largest fraction of vegetation $\leq$ height of 
Fig. 2. Relative growth rate for sugar maple seedlings, expressed as relative stem length growth, versus percent canopy openness for 1992 data. Each datum is a plot mean ( $n=101$ plots), based on $1-3$ seedlings per plot and 2-4 canopy openness measurements per plot. Plots for all sites were grouped for this analysis. The regression equation is relative growth rate $=0.0995+0.0116$ (percent canopy openness); $P=<0.0001 ; R^{2}=0.21$.

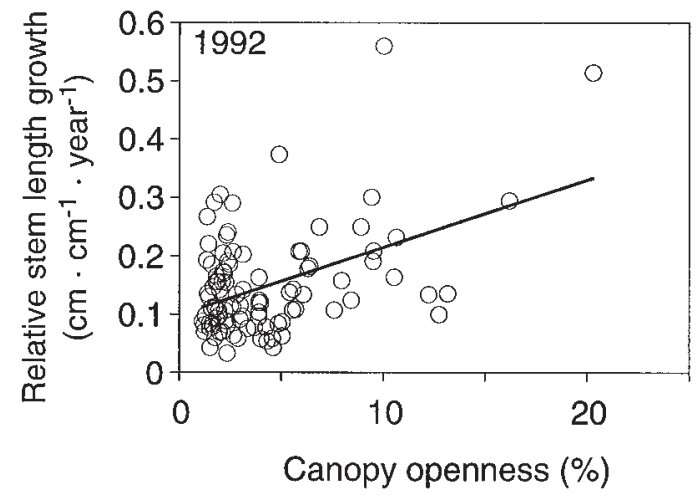

our measured seedlings on all 11 sites (Fig. 1). Compared with AViO sites, a lower proportion of all tree seedlings were sugar maple on AVVib and PMV sites (mean = 93\% vs. 48\%, respectively), but in terms of absolute numbers, sugar maple seedlings were abundant on all sites (Table 1).

Rates of total $\mathrm{N}$ mineralization $\left(\mathrm{NH}_{4}\right.$ and $\left.\mathrm{NO}_{3}\right)$ varied by over 2.5-fold and nitrification ( $\mathrm{NO}_{3}$ only) almost 7-fold across sites. AViO sites generally had higher $\mathrm{N}$ mineralization and had much higher nitrification rates than AVVib and PMV sites (Table 1). Percent sand in the first $20 \mathrm{~cm}$ of soil did not vary systematically with habitat type. The percent fine silt and clay $(<5.5 \mu \mathrm{m})$ fraction was very low on the four sites where it was measured. For the $0-20 \mathrm{~cm}$ depth it was $4.1,2.7,3.7$, and $2.8 \%$ and for $30-50 \mathrm{~cm}$ depth it was $3.3,3.3,3.6$, and $1.6 \%$ for $\mathrm{AViO}_{1}, \mathrm{AViO}_{2}, \mathrm{AVVib}_{1}$, and $\mathrm{PMV}_{1}$, respectively. Organic carbon tended to be higher and fine root mass lower in $\mathrm{AViO}$ than in AVVib and PMV sites, but trends were weak. There was also a weak trend of decreasing percent soil water from rich to poor habitat types, with $\mathrm{PMV}_{1}$ and $\mathrm{PMV}_{3}$ soils having the lowest values. Across sites, percent soil water was positively related to percent soil carbon (least squares regression, $\left.R^{2}=0.61, P=0.006\right)$ and negatively related to percent sand $\left(R^{2}=0.58, P=0.006\right)$.

Trends in soil properties across sites were similar for ALL LIGHT (based on all plots, Table 1) and LOW LIGHT (restricted to plots $<5 \%$ canopy openness) data sets. In fact, site means were not different between ALL LIGHT and LOW LIGHT by more than $5 \%$ for any soil characteristic, except organic carbon $(<12 \%)$, thus soil characteristic data for LOW LIGHT are not presented in tables.

\section{Canopy openness and seedling characteristics}

For ALL LIGHT data, canopy openness was highest for two partially cut sites $\left(\mathrm{AViO}_{4}, \mathrm{AVVib}{ }_{4}\right)$, lower for the three PMV sites, and lowest for the other AVVib, ATD, and AViO sites (Table 1). Seedling growth rates were generally ranked $\mathrm{AViO}>\mathrm{AVVib}>\mathrm{PMV}$, with the exception that growth was high for $\mathrm{AVVib}_{4}$. Of all resource indices measured, canopy openness was the only one related to growth after site effects
Fig. 3. (a) Sugar maple seedling percent leaf nitrogen versus percent canopy openness $\left(\log _{10}\right.$ scale $)$ for plot data. Plot values are for one leaf nitrogen sample pooled from the leaves of 1-3 seedlings. Plots are grouped by habitat type for the purpose of illustrating general differences among richer and poorer sites and are not intended to imply that habitat types are natural site groupings. For habitat type groupings, the regression equations for significant regressions' $R^{2}$ and $P$ values are PMV $, R^{2}=0.00, P=0.93$; AVVib, leaf $\mathrm{N}=1.48-0.38 \log _{10}$ (percent canopy openness), $R^{2}=0.15$, $P=0.024 ; \mathrm{AViO}$, leaf $\mathrm{N}=2.18-0.89 \log _{10}$ (percent canopy openness), $R^{2}=0.58, \mathrm{P}<0.0001$. (b) Sugar maple leaf mass ratio versus seedling age $\left(\log _{10}\right.$ scale). Data are pooled for seedlings harvested in 1990 and 1991. For the overall relationship (no habitat type groupings), regression summary statistics are leaf mass ratio $=$ $0.333-0.176 \log _{10}$ (age), $R^{2}=0.52, P<0.0001$.
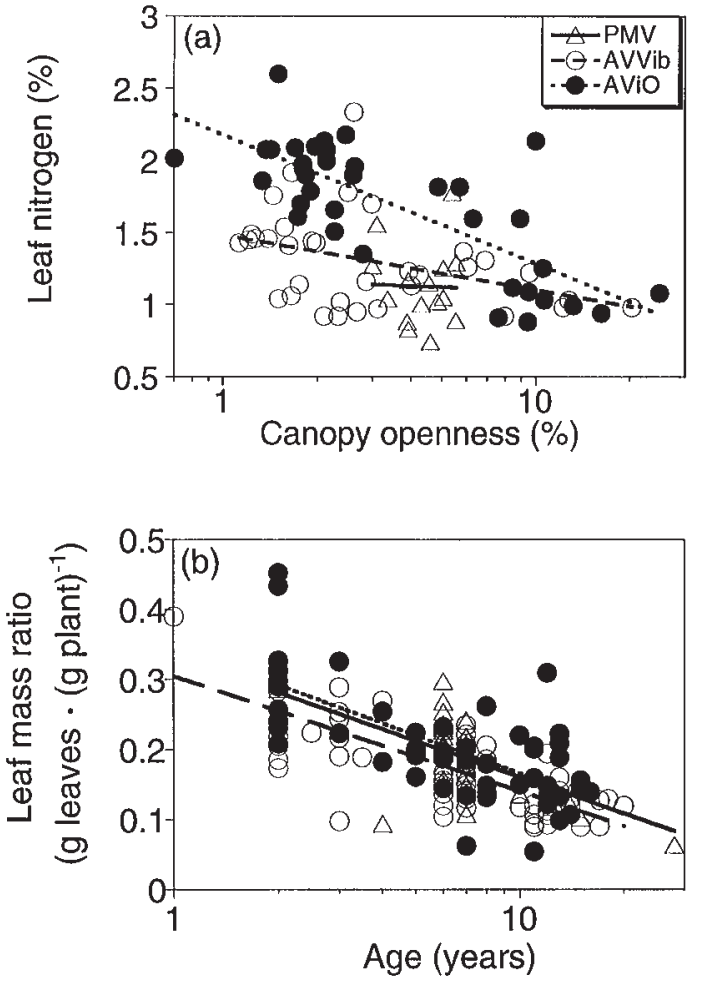

were removed (ANCOVA, $P<0.0001$ ). Canopy openness measured in either 1991 or 1992 was linearly related to 1992 stem length growth (least squares regression: for $1991 R^{2}=$ $0.18, P<0.0001, n=90$; for 1992, Fig. 2). Unlike 1992 growth responses, canopy openness measured in either 1991 or 1992 was not related to 1991 growth for seedlings harvested in 1991 or 1992 ( $P \geq 0.098$ for all four cases). This is surprising, since plots ranked similarly for canopy openness between years (see Site, materials, and methods).

Leaf $\mathrm{N}$ varied almost 2 -fold across sites (Table 1), with sites generally ranked $\mathrm{AViO}>\mathrm{AVVib} \cong \mathrm{PMV}$, except for $\mathrm{AViO}_{4}$, which had low leaf $\mathrm{N}$, but, importantly, high canopy openness. Pooling plots from all sites, canopy openness had a weak, negative effect on leaf $\mathrm{N}$ after site effects had been removed (ANCOVA, $P=0.098$ ). Pooling plots by habitat type (with ATD excluded from the analysis), the relationship between percent leaf $\mathrm{N}$ and canopy openness was highly significant for AViO sites (Fig. 3a), explaining the low average 
Fig. 4. The natural logarithm of whole plant mass versus the natural logarithm of total stem length for sugar maple seedlings excavated from four sites in $1990(n=88)$. Regression summary statistics are $\ln ($ plant mass $)=-\ln \left(\right.$ length $\left.^{2}\right) 0.1027+\ln ($ length $) 2.235-5.242$, $R^{2}=0.93, P<0.0001$.

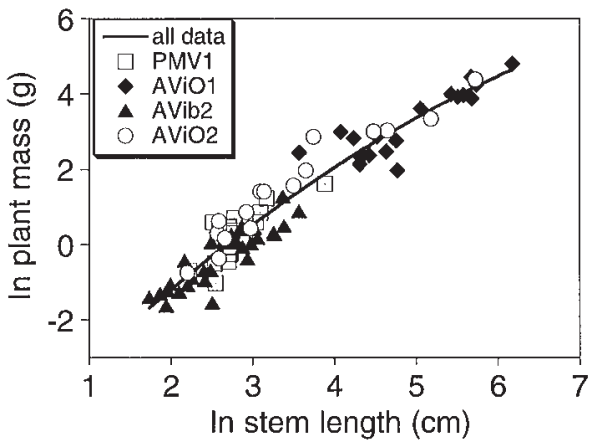

percent leaf $\mathrm{N}$ in $\mathrm{AViO}_{4}$, the site with the highest light. These relationships also suggest that leaf $\mathrm{N}$ tends to be higher for leaves from rich $\mathrm{AViO}$ sites than AVVib and PMV sites at similar light levels $<5 \%$ canopy openness (Fig. $3 a$ ). Leaf mass ratio (leaf mass.(total seedling mass) ${ }^{-1}$ ) was not related to canopy openness after site effects were removed (ANCOVA, $P=0.22$ ), but it was related to seedling age and mass, and the relationships were negative (ANCOVA, $P<0.0001$ for age and $P=0.0002$ for mass). When leaf mass ratios were normalized for differences in seedling age (Table 1, Fig. $3 b$ ) or mass (data not shown) there was no clear trend across habitat types. Consistent with our seedling selection criteria for modest stem dieback and herbivory, there was no indication that differences in dieback or herbivory affected leaf mass ratios or differences in growth across sites. Among sites in ALL LIGHT, partial leaf loss averaged $3.2 \%$ and was highest for ATD (11\%) and $\mathrm{AViO}_{2}$ (4\%) and lowest for $\mathrm{PMV}_{1}(0.7 \%)$ and AVVib 1 (1.7\%). The median number of stem diebacks was one per seedling and ranked highest (Kruskall-Wallis test, $P=0.0248$ ) for $\mathrm{AVVib}_{2}$ and $\mathrm{AVVib}_{4}$ (1 per seedling) and lowest for $\mathrm{AViO}_{3}$ and $\mathrm{PMV}_{2}(0)$.

\section{Relationships between seedling traits and soil variables in LOW LIGHT}

Our analysis focused on LOW LIGHT site means (the average of plots $<5 \%$ openness), since we were interested in soil resource - growth relationships under comparable levels of deep shade. This restricted set was considered necessary, since canopy openness affected growth and varied with site, thus obscuring relationships between site fertility and growth rate. We chose to use LOW LIGHT site means rather than means adjusted by the covariate canopy openness for the following reason. Although variation in canopy openness was continuous over a relatively broad range $(0.8-21 \%)$, data had a skewed positive distribution with few data at high canopy openness (e.g., for 27 of 101 , canopy openness was $>5 \%$, and for only 7 of 101 , canopy openness was $>10 \%$, Fig. 2). Analysis of levers (Huber 1981) revealed that the few high canopy openness values we had were often overly influential in determining the relationship between canopy openness and seedling traits in ANCOVA (i.e., levers $>0.20$ for values $>10 \%$ canopy openness were common, data not shown). Therefore, we had little confidence in the slope for the covariate predictor canopy openness and
Fig. 5. $(a-d)$. Site means in the Low Light data set (using only plots $<5 \%$ canopy openness) for seedling characteristics, percent canopy openness, and soil nitrification rates. Error bars (+1 SE) are for variation among plots. The 1991 and 1992 growth rates in Fig. $5 a$ are for seedlings harvested in 1992. Mass growth in 1992 was estimated from stem length (see Sites, materials, and methods and Fig. 4 for details). The number of plot values used for site means varied slightly among characteristics and were $\mathrm{AViO}_{1}(6-7)$, $\mathrm{AViO}_{2}(7-8), \mathrm{AViO}_{3}$ and ATD (8-9), AVVib 1 (10), $\mathrm{AVVib}_{2}$ and $\mathrm{AVVib}_{3}(9-10), \mathrm{PMV}_{1}(4-5), \mathrm{PMV}_{2}$ (7). Site habitat type nomenclature and rationale for the ordering of sites are in Table 1 note and Sites, materials, and methods.

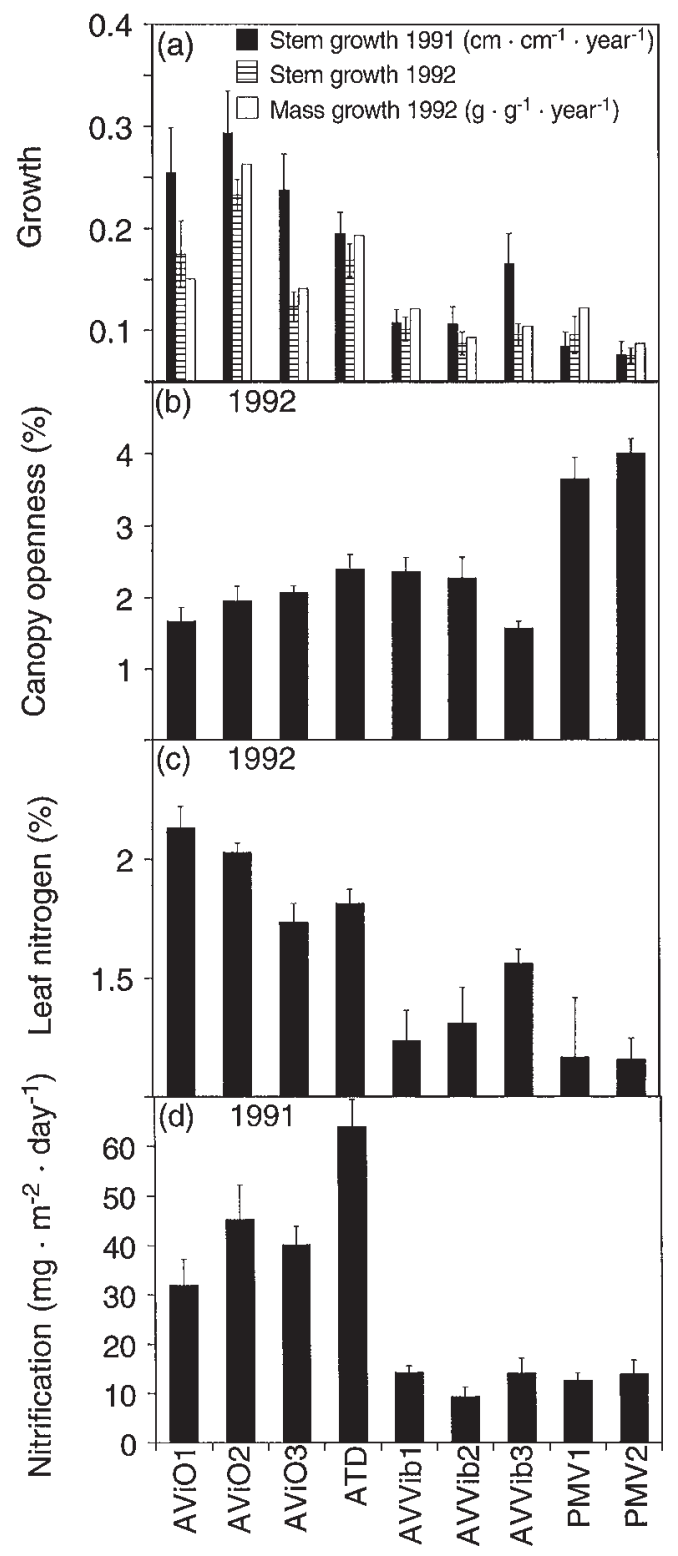

thus considered it risky to adjust means by canopy openness using ANCOVA.

Since the meaning of stem length as a measure of whole plant growth is uncertain, we estimated total plant dry mass using relationships between stem length and plant mass of additional harvested seedlings from plots and sites that cross the soil fertility and light gradient encompassed in this study (Fig. 4). 
Fig. 6. Relationships for Low Light site means ( $n=9$ sites) of (a) 1991 and 1992 seedling growth to nitrification rates and (b) 1991 seedling growth to percent soil water. Spearman's rank correlations for these relationships are in Table 2.
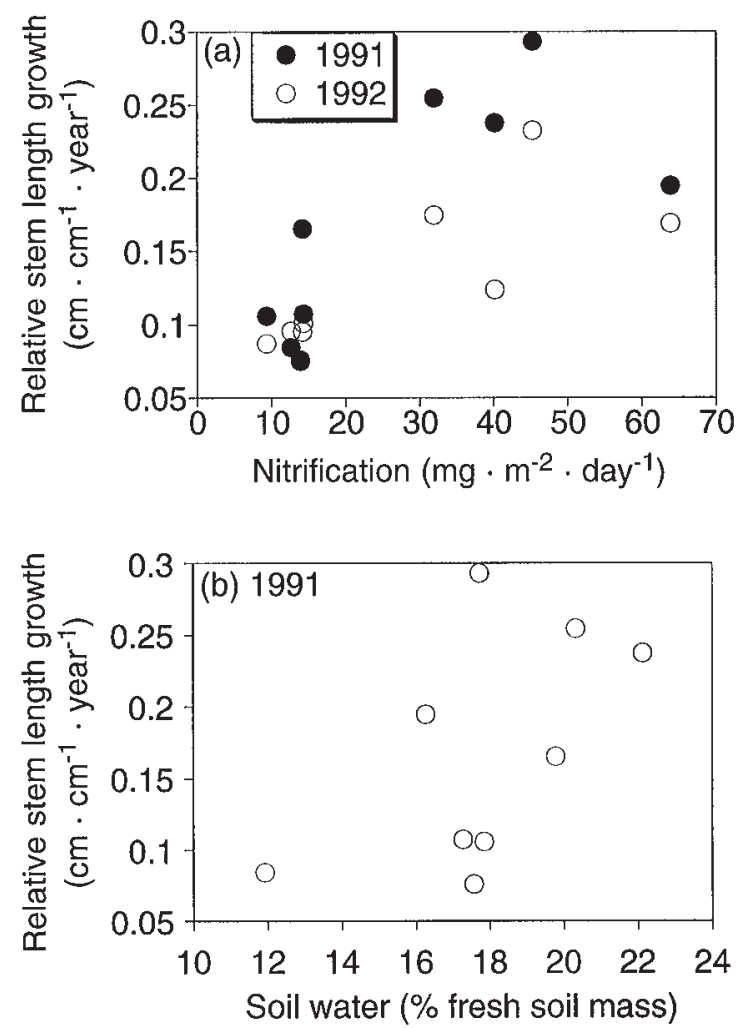

This relationship was strong and was similar across sites, indicating that stem length growth is a reasonable surrogate for whole plant growth (including both roots and aboveground growth).

For LOW LIGHT site means, seedling growth varied 3- to 4fold across sites, and trends were generally AViO $>$ AVVib $>$ PMV for all years and measures of growth (Fig. $5 a$ ) despite PMV sites having slightly greater canopy openness than the other sites (Fig. 5b). Variation in leaf $\mathrm{N}$ and nitrification rates were $\geq 2$-fold, and rankings across sites were similar to those for growth (Figs. $5 c$ and $5 d$ ). In contrast, leaf mass ratios, adjusted for variation in seedling age (ANCOVA), showed no trend across sites (data not shown). The pattern of leaf area ratio $\left(\mathrm{cm}^{2}\right.$ leaf $\left.\cdot(\mathrm{g} \text { plant mass })^{-1}\right)$ across sites was nearly identical with that for leaf mass ratio (data not shown), since there was very little variation in leaf mass per area $\left(\mathrm{g}\right.$ leaf $\cdot\left(\mathrm{m}^{2}\right.$ leaf) ${ }^{-1}$ ) among sites (range $\mathrm{AVVib}_{3}=24.7$ to $\mathrm{AViO}_{1}=27.0$ $\mathrm{g} \cdot \mathrm{m}^{-2}$ ). $\mathrm{N}$ mineralization and nitrification rates for 1991 were positively correlated with seedling growth rates for 1991 and 1992 (Table 2, Fig. $6 a$ for nitrification). Rank correlations were stronger for nitrification than total mineralization for both years. Percent soil water, measured in 1991, was weakly related to 1991 growth rates $(P=0.053$, Table 2, Fig. $6 b)$. However, the combined effects of nitrification rates and percent water explained $79 \%$ of the variation in 1991 growth (multiple linear regression, $P=0.009)$. In the mixed model both water $(P=0.033)$ and nitrification $(P=0.015)$ terms were significant and the residuals were distributed evenly with re-
Fig. 7. Actual versus predicted 1991 stem length growth for the model relative stem length growth $=$ nitrification $\operatorname{rates}(0.0027)+$ percent soil water $(0.0133)-0.1676, R^{2}=0.79, P=0.009$. Both percent soil water and nitrification rates were significant predictors of growth in the model (partial $P=0.033$ and 0.0147 , respectively), and they were not colinear $\left(R^{2}=0.03, P=0.66\right)$.

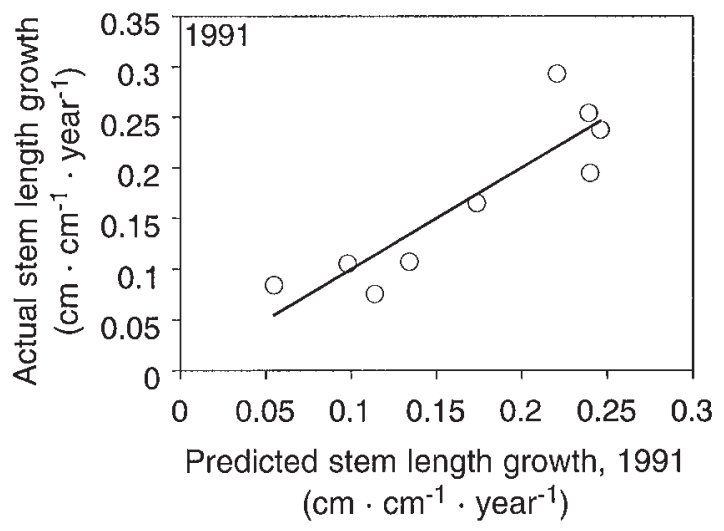

spect to predicted values (Fig. 7). Percent soil water and nitrification rates explained more variation in 1991 growth than any other two-variable combination for the seven predictor variables tested (percent soil water, percent soil carbon, percent sand, fine root density, nitrification rates, $\mathrm{N}$ mineralization rates, and seedling layer coverage) in relation to 1991 or 1992 growth, and they were the only two-variable growth model variable in which both terms were significant (data not shown). Nitrification rates correlated positively with percent leaf $\mathrm{N}$ (Fig. 8a) and negatively with fine root density (Fig. 8b). Thus, lower seedling growth in AVVib and PMV than in AViO and ATD understories was associated with low $\mathrm{N}$ and water availability, as indicated by soil water content, lower rates of nitrification, and perhaps higher competition for these resources (i.e., higher fine root density). Leaf $\mathrm{N}$ measured in 1992 was strongly associated with growth in both 1991 (Table 2) and 1992 (Table 2, Fig. 8c).

\section{Discussion}

In northeastern Wisconsin, regardless of the year or growth estimator considered, sugar maple seedling growth in lowlight understories varied 3-fold with regional variation in soil $\mathrm{N}$ and water availability. Seedling growth rates were correlated with rates of $\mathrm{N}$ mineralization $\left(\mathrm{NO}_{3}\right.$ and $\left.\mathrm{NH}_{4}\right)$ and more strongly with nitrification $\left(\mathrm{NO}_{3}\right.$ only). Although independently soil water content was only weakly related to growth, $79 \%$ of the variation in seedling growth could be explained by the combination of water content and nitrification rates. Growth rates were also positively correlated with soil organic carbon and negatively with fine root density. Collectively these results suggest that low nitrate and water availability, perhaps resulting from low potential availabilities (e.g., nitrification rates and soil physical properties) and higher competition (e.g., higher fine root density) may, along with light, co-limit sugar maple growth in forest understories.

\section{Variation in $\mathbf{N}$ and water availability across sites}

Nitrogen mineralization rates varied 2.5-fold and nitrification 7 -fold over sites of generally similar basal area, canopy closure 
Fig. 8. Relationships among seedling and resource availability indices. Data are for LOW LIGHT site means ( $n=9$ sites). (a) 1992 leaf nitrogen versus 1991 nitrification rates. (b) 1991 nitrification rates versus 1992 fine root density. (c) 1992 relative stem length growth versus 1992 leaf nitrogen. Spearman's rank correlations for these relationships are in Table 2.
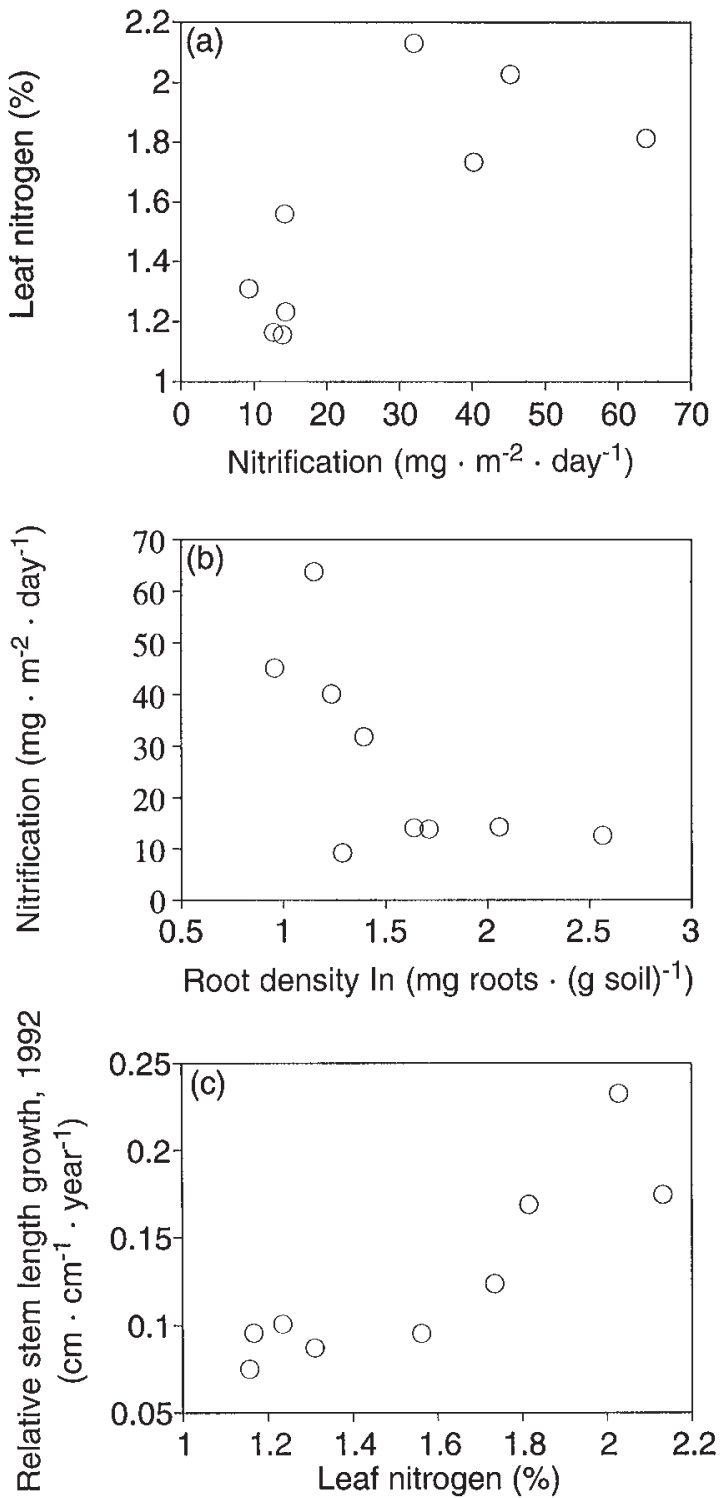

(when considering LOW LIGHT), and stand age but which differed in species composition, habitat type, and landform. Zak et al. (1989) found similar trends in $\mathrm{N}$ mineralization and nitrification in northern Michigan across what was probably a similar or wider range of landform-ecological associations (Quercus velutina Lam. - Quercus alba L. - Vaccinium to A. saccharum - Tilia americana L. - Osmorhiza) than we examined in northern Wisconsin. While our intent was not to test assumptions regarding the site fertility - habitat type classifications (Kotar et al. 1988), the patterns we found are suggestive. Generally patterns in $\mathrm{N}$ mineralization, nitrification, and water content are consistent with the relative fertility and moisture availabilities presumed by the habitat type system. AViO sites did generally have higher rates of $\mathrm{N}$ mineralization and soil water and always had higher rates of nitrification than AVVib and PMV sites. While soil moisture was lower for two of the three PMV sites than for any of the other sites, PMV sites had similar $\mathrm{N}$ mineralization and nitrification rates to AVVib sites.

Two of three LOW LIGHT AViO sites compared with no AVVib and PMV sites were partially cut 5 to 7 years before measurements, raising the possibility that higher seedling growth and (or) indices of belowground resource availability were a function of partial cutting rather than intrinsic site differences in nutrient and water availability. However, we do not consider this a strong possibility, since (1) compared with partially cut $\mathrm{AViO}$ sites, uncut $\mathrm{AViO}_{3}$ and $\mathrm{ATD}$ had similar nitrification rates, seedling growth, and fine root density and $\mathrm{AViO}_{3}$ had similar soil water; (2) partial cutting should influence seedling growth through higher light, water, and nutrient availability and lower competition (e.g., fine root density), which we estimated. A growth effect independent of these factors is unlikely.

\section{Nitrogen, water, and seedling growth}

Nitrogen and water availability effects on low-light seedling growth in northern Wisconsin are paralleled by the relationship of these resources to forest annual aboveground net primary productivity (ANPP) in the same region. For a broad range of evergreen conifer and broad-leaved deciduous stands in Wisconsin and Minnesota, Reich et al. (1996) found that ANPP increased with $\mathrm{N}$ mineralization. However, for any given $\mathrm{N}$ mineralization rate ANPP was higher on finer textured Alfisols than on sandy Entisols, suggesting that both water and $\mathrm{N}$ limit productivity. Although we found rates of nitrification and soil water content to be related to seedling growth in low light, other unquantified factors could have co-affected seedling growth across our sites. These factors may include other potentially limiting nutrients (e.g., Mg, Ca; Reich and Hinkley 1980), although we consider this unlikely, or spatial and temporal patterns of water availability that were unaccounted for in our study. Our moisture measurements were mostly limited to the first $20 \mathrm{~cm}$ of the soil profile, but McFadden et al. (1994) found that differences in soil texture that occur primarily at depths $>75 \mathrm{~cm}$ strongly affect oak forest productivity in Michigan. In addition, our gravimetric soil moisture measurements, taken only twice over the growing season, are only a crude index of long-term water availability to seedlings. Furthermore, variation in overstory leaf phenology among sites could drive differences in growth, if the overstory was leafless, while understory sugar maple seedlings were photosynthetically competent, for longer periods on rich than poor sites (Harrington et al. 1989; Ellsworth and Reich 1992). However, we do not believe that this is an important factor, since several of the less fertile sites' overstories contained a large $Q$. rubra component, which generally flushes leaves much later $(\sim 2$ weeks $)$ than the sugar maples that dominate rich sites (Reich et al.1991; M. Walters, personal observation).

Although we did find higher seedling growth rates in rich than poor understories, we acknowledge that our results apply only to similar low light levels. This is an important caveat, since the shade cast by young self-thinning stands may be deeper on rich than poor sites, in part because of the deeper shade cast by sugar maple relative to other canopy species common across our sites (Canham and Burbank 1994). 


\section{Seedling morphology, leaf $\mathbf{N}$, and growth}

Relationships between leaf N, nitrification, and fine root density suggest that $\mathrm{N}$ availability to the individual seedling is a positive function of $\mathrm{N}$ supply (nitrification) and a negative function of competition for that supply (fine root density). Increases in leaf $\mathrm{N}$ concentrations with site productivity have been reported for canopy sugar maple trees (Fownes 1985) but to our knowledge, not for seedlings in low-light understories. In addition we found strong relationships between leaf $\mathrm{N}$ and growth for low-light seedlings. Collectively, these results suggest that seedling growth is at least partially $\mathrm{N}$ limited on less fertile sites.

Although relationships between leaf $\mathrm{N}$ and growth are strong, a possible mechanistic basis for this relationship is unclear. Data for five sites in LOW LIGHT suggest that light-saturated photosynthetic rates (in $\mathrm{nmol} \mathrm{CO}_{2} \cdot(\mathrm{g} \mathrm{leaf})^{-1} \cdot \mathrm{s}^{-1}$ ) were higher on richer than poorer sites $\left(\mathrm{AViO}_{1}, 170 ; \mathrm{AViO}_{3}, 134 ; \mathrm{ATD}\right.$, 113; $\mathrm{PMV}_{3}, 112$; and $\left.\mathrm{PMV}_{2}, 109\right)$. However, although higher leaf (or whole-plant) $\mathrm{N}$ increases photosynthetic capacity and growth in high light for seedlings of temperate tree species (Walters and Reich 1989; Brown et al. 1995a, 1995b), these relationships have not been identified for seedlings growing in low light. Moreover, the potential benefits of higher leaf $\mathrm{N}$ in deep shade are unclear. Perhaps it does lead to higher photosynthetic capacity and increased growth during high light periods in spring before the overstory leaf canopy is fully developed (Harrington et al. 1989). In addition, leaf $\mathrm{N}$ is partitioned preferentially to the light capture components of photosynthesis in low light (Evans 1989; Ellsworth and Reich 1992), suggesting that higher leaf $\mathrm{N}$ could benefit growth by improving the efficiency of light capture.

In contrast with leaf $\mathrm{N}$, leaf mass ratio did not vary with $\mathrm{N}$ and water availability. Optimal allocation and multiple resource limitation theories predict increased allocation to carbon (light) acquisition function in low light, if nutrient availability is high (Chapin et al. 1987; Tilman 1988). This increase could be physiologically or biochemically based (e.g., increased concentration of metabolites required for photosynthesis) and (or) morphologically based (e.g., increased leaf mass or surface area). Our results indicate that leaf mass and leaf area ratio do not increase with $\mathrm{N}$ and water availability in low light for sugar maple. This suggests that sugar maple does not optimize allocation to multiple limiting resources through shifts in leaf biomass or area. Our data do not provide support for or against optimal biochemical-physiological allocation, since (1) higher leaf $\mathrm{N}$ in fertile sites does not necessarily indicate preferential allocation to leaf over root function, because $\mathrm{N}$ could increase equally in leaves and roots and (2) we have data only on leaf $\mathrm{N}$ and not on $\mathrm{N}$-dependent photosynthetic metabolites.

\section{Potential implications for community dynamics}

Interspecific differences in shade tolerance have been implicated as the predominant mechanism driving forest succession (Spurr and Barnes 1980; Pacala et al. 1996). Among species, shade tolerance is associated with higher survival in low light (Augspurger 1984; Kobe et al. 1995; Walters and Reich 1996), with the probability of survival for individuals within a species being a positive function of their relative growth rate (Kobe et al. 1995; Walters and Reich 1996). While we do not have survival data for this experiment, higher growth rates in rich understories suggests that shade tolerance (i.e., persistence in low light understories) may be enhanced on these sites. Survival in low light has been shown to be increased by high soil fertility independent of growth rate (Kobe et al. 1995). However, to our knowledge, except for this experiment and that of Carter and Klinka (1992) there has been little evidence for soil resources affecting tree seedlings' growth at low light levels for naturally established seedlings. Carter and Klinka (1992) suggest that Douglas-fir (Pseudotsuga menziesii (Mirb.) Franco) is more shade tolerant on dry than moist sites, since it takes less light to achieve a given level of relative growth performance on dry sites. However, their data are difficult to compare with ours, since their measure of growth for seedlings in shade is relativized to the maximum high-light seedling growth rates for that particular type of site (i.e., dry, moist, etc.). Pacala et al. $(1994,1996)$ report no evidence that variation in water or $\mathrm{N}$ availability affects growth for saplings of 13 forest tree species common in the eastern deciduous forests of Connecticut. Their conclusions are based on trenching experiments and assessments of growth as a function of covariation in soil $\mathrm{N}$ mineralization and volumetric water content. Differences in our results could be due to the allometric scalars used to estimate growth (Pacala et al. 1994), size of individuals studied (they used mostly larger saplings), the geographic breadth of the studies (they used a smaller contiguous forested area), or differences in growth limitations between Connecticut and Wisconsin temperate deciduous forests. Differences in seedling growth rates across landscape-scale gradients of $\mathrm{N}$ and water availability could have implications for community dynamics, since lower growth on less fertile sites could slow the rate at which sugar maple invades these stands via lower rates of survival and canopy ascension.

\section{References}

Attig, J.W. 1985. Pleistocene geology of Vilas County, Wisconsin. Wis. Geol. Nat. Hist. Surv. Inf. Circ. 50.

Augspurger, C.K. 1984. Light requirements of neotropical tree seedlings: a comparative study of growth and survival. J. Ecol. 72: 777-795.

Beatty, S.W. 1984. Influence of microtopography and canopy species on spatial patterns of forest understory plants. Ecology, 65: 1406-1419.

Binkley, D., and Hart, S. 1989. The components of nitrogen availability assessments in forest soils. Adv. Soil Sci. 10: 57-112.

Black, C.A., Evans, D.D., White, J.L., Ensminger, L.E., and Clark, F.E. (Editors). 1965. Methods of soil analysis. Parts 1 and 2. Agronomy, 9.

Brown, K.R., Thompson, W.A., and Weetman, G.F. 1995a. Effects of $\mathrm{N}$ addition rates on the productivity of Picea stichensis, Thuja plicata and Tsuga heterophylla seedlings. I. Growth rates, biomass allocation and macroelement nutrition. Trees, 10: 189-197.

Brown, K.R., Thompson, W.A., Camm, E.L., Hawkins, B.J., and Guy, R.D. 1995b. Effects of $\mathrm{N}$ addition rates on the productivity of Picea stichensis, Thuja plicata andTsuga heterophylla seedlings. II. Photosynthesis, ${ }^{13} \mathrm{C}$ discrimination, and $\mathrm{N}$ partitioning in foliage. Trees, 10: 198-205.

Canham, C. 1988. Growth and canopy architecture of shade tolerant trees: the response of Acer saccharum and Fagus grandifolia to canopy gaps. Ecology, 69: 786-795.

Canham, C., and Burbank, D. 1994. Causes and consequences of resource heterogeneity in forests: interspecific variation in light transmission for canopy trees. Can. J. For. Res. 24: 337-349.

Carter, R.E., and Klinka, K. 1992. Variation in shade tolerance of 
Douglas fir, western hemlock, and western red cedar in coastal British Columbia. For. Ecol. Manage. 55: 87-105.

Chapin, F.S., III, Bloom, A.J., Field, C.B., and Waring, R.H. 1987. Plant responses to multiple environmental factors. BioScience, 37: 49-57.

Clark, J.S. 1990. Landscape interactions among nitrogen mineralization, species composition, and long-term fire frequency. Biogeochemistry, 11: 1-22.

Curtis, J.T. 1959. The vegetation of Wisconsin: An ordination of plant communities. The University of Wisconsin Press, Madison, Wis.

DiStefano, J., and Gholz, H.L. 1986. A proposed use of ion exchange resin to measure nitrogen mineralization and nitrification in intact soil cores. Commun. Soil Sci. Plant Anal. 17: 989-998.

Ellsworth, D.E., and Reich, P.B. 1992. Leaf mass per area, nitrogen content and phtotsynthetic carbon gain in Acer saccharum seedlings in contrasting forest light environments. Funct. Ecol. 6: 423-435.

Evans, J.R. 1989. Photosynthesis and nitrogen relationships in leaves of $\mathrm{C}_{3}$ plants. Oecologia, 78: 9-19.

Fownes, J.H. 1985. Water use and primary production of Wisconsin hardwood forests. Dissertation, University of Wisconsin, Madison, Wis.

Givnish, T.J. (Editor). 1986. On the economy of plant form and function. Cambridge University Press, Cambridge, England.

Givnish, T.J. 1988. Adaptation to sun and shade: a whole-plant perspective. Aust. J. Plant Physiol. 15: 63-92.

Grubb, P.J. 1994. A paradox of root competition: a possible resolution and implications. Phytocoenologia, 24: 495-506.

Harrington, R.A., Brown, B.J., and Reich, P.B. 1989. Ecophysiology of exotic and native shrubs in southern Wisconsin; 1. relationship of leaf characteristics, resource availability, and phenology to seasonal patterns of carbon gain. Oecologia, 80: 356-367.

Host, G.E., Pregitzer, K.S., Ramm, C.W., Hart, J.B., and Cleland, D.T. 1987. Landform-mediated differences in successional pathways among upland forest ecosystems in northwestern lower Michigan. For. Sci. 33: 445-457.

Huber, P.J. 1981. Robust statistics. John Wiley \& Sons, New York.

Kobe, R.K., Pacala, S.W., Silander, J.A., and Canham, C.D. 1995. Juvenile tree survivorship as a component of shade tolerance. Ecol. Appl. 3: 517-532.

Kotar, J., Kovach, J.A., and Locey, C.T. 1988. Field guide to forest habitat types of northern Wisconsin. Department of Forestry, University of Wisconsin-Madison and the Wisconsin Department of Natural Resources, Madison, Wis.

Küppers, M. 1985. Carbon relations and competition between woody species in a central European hedgerow. IV Growth form and partitioning. Oecologia, 66: 343-352.

Lambers, H., and Poorter, H. 1992. Inherent variation in growth rate between higher plants: a search for physiological and ecological consequences. Adv. Ecol. Res. 23: 188-261.

Lei, T.T., and Lechowicz, M.J. 1990. Shade adaptation and shade tolerance in saplings of three Acer species from eastern North Amercia. Oecologia, 84: 224-228.

Lorimer, C.G. 1983. A test of the accuracy of shade-tolerance classifications based on physiognomic and reproductive traits. Can. J. Bot. 61: 1595-1598.

McFadden, J.P., MacDonald, N.W., Witter, J.A., and Zak, D.R. 1994. Fine-texture soil bands and oak productivity in northwestern lower Michigan, U.S.A. Can. J. For. Res. 24: 928-933.
Mooney, H.A., Fichtner, K., and Schultze, E-D. 1995. Growth, photosynthesis and storage of carbohydrates and nitrogen in Paseolus lunatus in relation to resource availability. Oecologia, 104: 17-23.

Pacala, S.W., Canham, C.D., Silander, J.A., Jr., and Kobe, R.K. 1994. Sapling growth as a function of resources in a north temperate forest. Can. J. For. Res. 24: 2172-2183.

Pacala, S.W., Canham, C.D., Saponara, J., Silander, J.A., Jr., Kobe, R.K., and Ribbens, E. 1996. Forest models defined by field measurements: II. Estimation, error analysis and dynamics. Ecol. Monogr. 66: 1-43.

Pastor, J., Aber, J.F., McClaughterty, C.A., and Melillo, J.M. 1984. Aboveground production and $\mathrm{N}$ and $\mathrm{P}$ cycling along a mineralization gradient on Blackhawk Island, Wisconsin. Ecology, 65: 256-268.

Peace, W.J.H., Grubb, P.J. 1982. Interaction of light and mineral nutrient supply in the growth of Impatiens parviflora. New Phytol. 90: $127-150$

Pearcy, R.W. 1983. The light environment and growth of $\mathrm{C}_{3}$ and $\mathrm{C}_{4}$ tree species in the understory of a Hawaiian forest. Oecologia, 25: $19-25$.

Reich, P.B., and Hinckley, T.M. 1980. Water relations, soil fertility and plant nutrient composition of a pygmy oak ecosystem. Ecology, 61: 400-416.

Reich, P.B., Walters, M.B., and Ellsworth, D.S. 1991. Leaf development and season influence the relationships between leaf nitrogen, leaf mass per area and photosynthesis in maple and oak trees. Plant Cell Environ. 14: 251-259.

Reich, P.B., Grigal, D.F., Aber, J.D., and Gower, S.T. 1997. Nitrogen mineralization and productivity in 50 hardwood and conifer stands on diverse soils. Ecology. In press.

Sipe, T.W., and Bazzaz, F.A. 1994. Gap partitioning among maples (Acer) in central New England: shoot architecture and photosynthesis. Ecology, 75: 2318-2332.

Sipe, T.W., and Bazzaz, F.A. 1995. Gap partitioning among maples (Acer) in central New England: survival and growth. Ecology, 76: $1587-1602$.

Spurr, S.H., and Barnes, B.V. 1980. Forest ecology. 3rd ed. John Wiley \& Sons, New York.

Tilman, D. 1988. Plant strategies and dynamics and structure of plant communities. Princeton University Press, Princeton, N.J.

Walters, M.B., and Reich, P.B. 1989. Response of Ulmus americana seedlings to varying nitrogen and water status. I. Photosynthesis and growth. Tree Physiol. 5: 159-172.

Walters, M.B., and Reich, P.B. 1996. Are shade tolerance, survival, and growth rate linked? Effects of low light and nitrogen on hardwood seedlings. Ecology, 77: 841-853.

Walters, M.B., Kruger, E.L., and Reich, P.B. 1993. Relative growth rate in relation to physiological and morphological traits for northern hardwood seedlings: species, light environment and ontogenetic considerations. Oecologia, 96: 219-231.

Zak, D.R., and Pregitzer, K.S. 1990. Spatial and temporal variability of nitrogen cycling in northern lower Michigan. For. Sci. 36: 367-38.

D.R., Host, G.E., and Pregitzer, K.S. 1989. Regional variability in nitrogen mineralization, nitrification, and overstory biomass in northern Lower Michigan. Can. J. For. Res. 19: 1521-1526. 